\title{
KEBIJAKAN SEKOLAH DALAM MENANGANI KEKERASAN SISWA DI SMA NEGERI 1 DEPOK SLEMAN YOGYAKARTA
}

\author{
SCHOOL POLICY TO TAKE IN HAND ON STUDENTS VIOLENCES AT SMA \\ NEGERI 1 DEPOK SLEMAN YOGYAKARTA
}

\author{
Endri Wahyu Setiyo Wati \\ Filsafat dan Sosiologi Pendidikan, Kebijakan Pendidikan FIP UNY \\ endriwahyu96@gmail.com
}

\begin{abstract}
Abstrak
Penelitian ini bertujuan mengetahui dan mengidentifikasi kebijakan sekolah dalam menangani kekerasan siswa di sekolah. Metode penelitian menggunakan pendekatan kualitatif dengan jenis penelitian deskriptif. Pengumpulan data dengan pengamatan, wawancara, dan studi dokumentasi. Teknik analisis data menggunakan teori Miles and Hubberman. Sedangkan keabsahan data menggunakan triangulasi teknik dan sumber. Hasil penelitian ini adalah sebagai berikut : (1) program sekolah dalam menangani kekerasan siswa di sekolah seperti pengawalan dan pengontrolan kegiatan kesiswaan, literasi keagamaan, optimalisasi peran Bimbingan Konseling, dan penegakan tata tertib. (2) pelaksanaan program sekolah dalam menangani kekerasan siswa di sekolah yaitu merujuk pada aspek komunikasi, sumber daya, sarana dan prasarana, alokasi waktu, sturktur birokrasi, dan sikap pelaksana. (3) faktor pendukung; kerjasama warga sekolah, peran personil pelaksana, dan sistem organisasi yang berjalan dengan baik. Faktor penghambatnya adalah cara pandang orangtua terhadap karakter anaknya. Sedangkan cara mengatasi faktor penghambat tersebut adalah memberikan forum komunikasi antara pihak terkait dengan memberikan bukti-bukti valid dari sekolah.
\end{abstract}

Kata Kunci : kebijakan sekolah, kekerasan siswa di sekolah

\section{Abstract}

The goals of the research are to know and identify policy education that be used to handle students violences at school. The method of this research used approximation qualitative with descriptive reseacrh. Data is colleted by observation, interview and documentations. The analysis of data used Miles and Hubberman theory. The other component is validation of the data. It used triangulation of technique and resources. The outputs of this reaseacrh are (1) School program to handle students violences at school. (2) The implementation of school programs is to handle students violences at SMA Negeri 1 Depok Sleman Yogyakarta based on communication aspect, resources, medium and infrastructure, time allocation, structure of bureaucracy, and demeanor of implementer. (3) The supporting element of this program is collaboration of all components of school, the influences of executors, and the system organization. Blocked factor is point of view of the student's parents about characteristic of their children. The way to solve it is give discussion and communication forum with valid evidences from school.

Keywords: School policy, students violence 


\section{PENDAHULUAN}

Kekerasan di sekolah sudah bukan hal langka yang terjadi. Adanya tindakantindakan kekerasan yang terjadi disekolah dapat dikategorikan dengan berbagai kategori tindak kekerasan. Berdasarkan hasil penelitian Ariefa Efianingrum (2007) bahwa kekerasan yang sering muncul dapat berupa kekerasan fisik yang mudah terlihat. Dan juga dapat berupa kekerasan non-fisik yang bersifat sublime misalnya kekerasan psikis, verbal, dan simbolis. Hal ini akan berdampak pada psikis atau perasaan tertekan. Jenis kekerasan yang bersifat sublime ini juga menjadi kekerasan yang paling banyak terjadi, dan akan menimbulkan kekerasan dalam bentuk lain.

Data KPAI (Komisi Perlindungan Anak Indonesia) dalam Nandang Mulyasa, dkk (2018) menunjukkan bahwa tren jumlah kekerasan pada anak terjadi peningkatan selama tahun 2011 - 2014. Yaitu pada tahun 2011 sebanyak 2178 kasus kekerasan, pada tahun 2012 sebanyak 3512 kasus kekerasan, pada tahun 2012 sebanyak 4311 kasus kekerasan, dan pada tahun 2014 sebanyak 5066 kasus kekerasan yang terjadi di Indonesia. Sedangkan pada tahun 2016 tercatat peningkatan 1000 kasus kekerasan, 136 kasus diantaranya adalah kekerasan yang diakibatkan oleh pengaruh media sosial serta yang berakibat pada bullying. Tindak kekerasan yang terjadi tersebut dilakukan oleh warga sekolah sendiri. Pihak yang biasa terlibat diantaranya guru maupun teman sebaya dari korban kekerasan disekolah tersebut. Seperti hasil penelitian dari Septasari Handayani yang berjudul tindak kekerasan fisik kalangan siswa sekolah menengah atas tahun 2014/2015 (studi kasus di SMA
Kota Surabaya) bahwa tindak kekerasan

fisik yang paling sering disaksikan dan dilaporkan siswa ke sekolah adalah berkelahi. Dari hasil penelitiannya juga dijelaskan bahwa siswa melakukan kekerasan fisik seperti berkelahi, pukulan, kucing-kucingan, cubitan, gigitan, dan dorongan.

Lembaga pendidikan yang menjadi penyumbang angka kekerasan disekolah terbanyak adalah tindak kekerasan yang terjadi di Sekolah Menengah Atas dibandingkan dengan tingkat pendidikan yang lainnya. Hal tersebut sesuai dengan hasil penelitian yang bersumber dari data Kantor Polrestas Kota Yogyakarta dan Polres Bantul tahun 2016-2017 bahwa pada siswa tingkat SD sebanyak 0 yang menjadi pelaku kekerasan. Pada tingkat pendidkan Sekolah Menengah Pertama (SMP) sebanyak 11 pelaku kekerasan. Pada tingkat pendidikan Sekolah Menengah Atas (SMA) sebanyak 71 pelaku aksi kekerasan. Perguruan Tinggi sebanyak 0 pelaku aksi kekerasan, pengangguran sebanyak 12 aksi pelaku kekerasan, dan home schooling sebanyak 2 pelaku aksi kekerasan. Dari data tersebut dapat disimpulkan bahwa tingkat pendidikan yang paling banyak terlibat dalam aksi kekerasan adalah pada tingkat pendidikan Sekolah Menengah Atas (SMA) atau sederajat.

Berdasarkan hasil observasi lapangan, dijelaskan oleh Dra. Wahyu Sri Nurjati selaku guru BK SMA Negeri 1 Depok Sleman Yogyakarta (2020) didapatkan data bahwa dahulunya sekolah ini sering terjadi beberapa kekerasan yang dilakukan oleh siswa. Baik kekerasan secara internal sekolah maupun kekerasan dengan eksternal sekolah seperti tawuran antar pelajar. Hal tersebut dipicu dengan adanya gang yang dibentuk oleh siswa di SMA Negeri 1 Depok Yogyakarta. BBC (Barikade Bocah Cuek) merupakan gangs yang ada di SMA Negeri 1 Depok Yogyakarta yang sudah dikenal dan disegani ditingkat sekolah menengah di 
Yogyakarta. Pada tahun 2013 BBC masih turut terlibat dalam tawuran antar pelajar di Yogyakarta, selain tawuran dijalan juga melakukan kegiatan sparing di sekolahnya sendiri.

Gang Barikade Bocah Cuek (BBC) di SMA Negeri 1 Depok Sleman Yogyakarta mulai lima tahun terakhir dapat dikatakan mati suri. Gang tersebut terdiri dari dua struktur, yaitu gang yang berasal dari SMA Negeri 1 Depok sendiri dan gang yang terdiri dari sekolah-sekolah luar SMA Negeri 1 Depok yang bergabung dalam Barikade Bocah Cuek (BBC). Beberapa kegiatan- kegiatan seperti tawuran antar sekolah yang dipicu oleh blayer-blayer motor sudah tidak lagi terjadi. Sikap senioritas yang dahulunya dilakukan kakak tingkat terhadap penguasaan larangan untuk melewati lapangan tengah basket, saat ini tidak terjadi lagi. Hal tersebut menunjukkan penurunan angka kekerasan verbal maupun non verbal dari SMA Negeri 1 Depok yang berkurang. Hal tersebut berdasarkan hasil observasi lapangan yang dilakukan peneliti pada Januari 2020.

Berdasarkan hasil penelitian Cintia Kusuma Dewi (2015) djelaskan bahwa terdapat 6 siswa dengan presentase 3,10\% memiliki kategori perilaku bullying sangat tinggi, sedangkan 6 siswa dengan presentase $3,10 \%$ memiliki perilaku bullying tinggi, 42 siswa dengan persentase $22,00 \%$ memiliki kategori perilaku bullying sedang, selain itu terdapat 94 siswa dengan persentase 49,20\% memiliki kategori perilaku bullying rendah, dan 43 siswa dengan persentase $22,50 \%$ memiliki kategori perilaku bullying sangat rendah. Dan perilaku bullying yang dilakukan siswa adalah meneriaki dan mempermalukan teman didepan umum, memanggil teman dengan julukan, menyebar gosip, melakukan terror atau ancaman untuk mendapatkan apa yang diinginkan. Hal tersebut dapat disimpulkan bahwa mayoritas siswa SMA Negeri 1 Depok Yogyakarta memiliki perilaku bullying kategori rendah dengan persentase $22,50 \%$.

Pendidikan di sekolah agar terbebas dari kekerasan tentunya dapat teratasi dengan berbagai hal. Hal itu dapat dilakukan dengan cara memahami penyebab kekerasan disekolah tersebut, mengenal lebih dalam kondisi sosial yang bisa menyebabkan perilaku kekerasan, dan mengkaji suasana kekerasan yang mampu menimbulkan kekerasan, hal tersebut dijelaskan oleh Dom Helder Camara dalam Abd. Rahman Assegaf (2004: 79). Dengan diketahuinya sebab dari suatu tindak kekerasan pasti akan timbul solusi untuk menangani tindak kekerasan siswa disekolah. Solusi tersebut langsung dipahami dan diketahui oleh sekolah yang bersangkutan, yang kemudian diturunkan dalam suatu kebijakan sekolah dalam menangani tindak kekerasan siswa di sekolah.

Tujuan dari penelitian ini adalah untuk mengetahui dan mengidentifikasi kebijakan sekolah dalam menangani kekerasan siswa di SMA Negeri 1 Depok Sleman Yogyakarta. Penelitian ini bermanfaat sebagai rekomendasi kepada berbagai lembaga untuk menangani permasalahan-permaslaahan pendidikan khususnya adalah permasalahan kekerasan siswa di sekolah.

\section{METODE PENELITIAN}

\section{Pendekatan dan Jenis Penelitian}

Pendekatan yang digunakan dalam penelitian ini adalah pendekatan kualitatif, dengan jenis penelitian deskriptif. Pendekatan kualitatif deskriptif merupakan penelitian yang hasil dari penelitiannya berupa deskripsi kata-kata dan gambar. Penelitian deskriptif merupkana 
penelitian yang berusaha untuk melakukan pemecahan masalah berdasarkan data-data, sehingga dapat menyajikan data, menganalisis, dan menginterprestasi. Sedangkan ciri-ciri dari penelitian deskriptif ini adalah menyajikan potret keadaan yang bisa mengajukan hipotesis atau tidak, merancang cara pendekatannya seperti data, penentuan sampel, penentuan metode pengumpul data, mengumpulkan data, dan Menyusun laporan, hal tersebut dijelaskan oleh Cholid Narbuko dan Abu Achmadi (2015: 42). Penelitian kualitatfi merupakan penelitian yang ditujukan untuk mendeskripsikan dan menganalisis suatu peristiwa, fenomena, tindakan, dan semua kegiatan yang akan diteliti yang mengarah pada pengambilan kesimpulan. Deskripsi menjadi salah satu poin utama dalam menyususn penelitian kualitatif. Hal tersbeut dijelaskan oleh Nana Syaodih (2009: 60).

\section{Waktu dan Tempat Penelitian}

Penelitian ini dilaksanakan dengan waktu peneltian yang singkat selama satu bulan, dengan mengahsilkan data yang komprehensif. Bertempat di SMA Negeri1 Depok Sleman Yogyakarta. Penelitian ini dilakukan pada tanggal 15 Januari 2020 sampai dengan 13 Februari 2020. Penentuan SMA Negeri 1 Depok Sleman Yogyakarta sebagai setting penelitian karena sekolah berhasil mengatasi permasalahan kekerasan, sehingga dilakukan kajian tentang kebijakannya dalam menangani kekerasan di sekolah.

\section{Subyek Penelitian}

Informan penelitian yang sedikit yaitu sebanyak Sembilan informan, dengan didapatkan hasil data yang komprehensif. Subyek dalam penelitian ini adalah pihak-pihak yang terlibat dalam kebijakan sekolah baik dari perencanaan sampai pada pelaksanaan. Pihak yang dilibatkan adalah kepala SMA Negeri 1 Depok Sleman Yogyakarta sebanyak satu orang, Wakil Kepala SMA Negeri 1 Depok Sleman Yogyakarta sebanyak satu orang, guru dan karyawan sebanyak satu orang, serta siswa-siswi SMA Negeri 1 Depok Sleman Yogyakarta sebanyak enam orang.

\section{Teknik Pengumpulan Data}

Teknik pengumpulan data yang digunakan adalah dengan cara observasi, wawancara, dokumentasi.

\section{Teknik Analisis Data}

Teknik analisis data yang digunakan dalam penelitian ini adalah menggunakan analisis sebelum dilapangan yaitu untuk menentukan fokus penelitian yang bersifat sementara dan bisa berubah sesuai kondisi lapangan. Setelah itu menggunakan analisis selama dilapangan yaitu dengan menggunakan teori Miles and Huberman yaitu reduksi data, penyajian data, dan pengambilan kesimpulan, hal tersbeut dijelaskan oleh Sugiyono (2011: 336-345).

\section{HASIL PENELITIAN DAN PEMBAHASAN \\ Program sekolah dalam menangani kekerasan siswa di sekolah}

Menurut Jones (1995) dalam Hasbullah (2008: 38) dijelaskan bahwa suatu kebijakan haruslah memiliki komponen-komponen untuk menjadi suatu kebijakan yang utuh, diantaranya adalah: goal (tujuan), plan (perencanaan), program (program), decision (keputusan), dan effect (dampak). Aspek tujuan dijelaskan bahwa menyusun kebijakan yang efektif perlu ditentukan tujuan utama dari adanya kebijakan tersebut untuk apa, sehingga kebijakan dapat 
diukur indikator keberhasilannya. Aspek perencanaan dijelaskan bahwa untuk mencapai tujuan dibutuhkan suatu perencanaan-perencanaan. Untuk mewujudkan dan melanjutkan perencanaan-perencanaan diperlukan suatu wacana yaitu dengan adanya program. Kebijakan dapat berjalan diperlukan suatu Tindakan dan keputusan sehingga dapat untuk mencapai tujuan, membuat rencana, melaksankan, dan menilai. Dan dalam pelaksanaan suatu kebijakan tentu menimbulkan suatu hal yang biasa disebut dengan adanya dampak.

Kebijakan yang diterapkan di SMA Negeri 1 Depok Sleman Yogyakarta agar berjalan efektif dalam menangani kekerasan siswa di sekolah memiliki beberapa aspek komponen yang tergantung didalamnya. Sesuai yang dikemukakan oleh Jones (1995) dalam Hasbullah (2008: 38) terkait komponenkomponen agar kebijakan menjadi efektif yaitu dengan adanya tujuan (goals), perencanaan (plan), program (programs), Tindakan (decision), dan dampak (effect). Tujuan kebijakan sekolah dalam menangani kekerasan siswa di SMA Negeri 1 Depok Sleman Yogyakarta adalah menekan tindakan kekerasan yang dilakukan siswa di sekolah. Gang Barikade Bocah Cuek (BBC) menjadi salah satu wadah untuk siswa melakukan potensi kekerasan. Kekerasan yang terjadi saat ini termasuk dalam kategori sedang, yaitu adanya pembelaan terhadap kelompok tertentu, terkait dengan fisik, adanya pelanggaran aturan lembaga pendidikan, hal tersebut juga dijelaskan oleh Abd. Rahman Assegaf (2004: 43) terkait dengan tingkatan-tingkatan kekerasan dalam pendidikan. Adanya hal tersebut, maka diterapkan kebijakan sekolah untuk menangani kekerasan tersebut. Pada kebijakan sekolah yang diterapkan dapat bersifat pencegahan maupun penanganan.

Perencanaan (plan) merupakan perencanaan-perencanaan yang direncakan untuk mencapai tujuan hal tersebut dijelaskan oleh Jones (1995) dalam Hasbullah (2008: 38). Kebijakan sekolah dalam menangani kekerasan siswa di SMA Negeri 1 Depok Sleman Yogyakarta adalah dengan melakukan komunikasi dengan seluruh warga sekolah. Terutama komunikasi dengan siswa yang menjadi pelaku utama kebijakan sekolah tersebut. komunikasi yang dilakukan adalah dengan mengadakan kegiatan sarasehan kesiswaan yang dihadiri oleh masing-masing ketua kelas dan ekstrakurikuler. Sehingga aspirasi siswa yang diwakili oleh masingmasing ketua akan tersampaikan kepada pengambil kebijakan.

Program (program) merupakan suatu wacana untuk mewujudkan serta melanjutkan rencana-rencana yang sudah yang ada dan digunakan untuk mencapai tujuan, seperti yang dijelaskan oleh Jones (1995) dalam Hasbullah (2008: 38). Untuk mencapai sebuah tujuan yaitu menekan tindakan-tindakan yang bersifat kekerasan, SMA Negeri 1 Depok Sleman Yogyakarta memiliki program sekolah yang dilaksanakan. Program sekolah untuk menangani kekerasan siswa di SMA Negeri 1 Depok Sleman Yogyakarta adalah adanya pengawalan dan pengontrolan kegiatan kesiswaan, seperti penghapusan ekstrakurikuler yang berhubungan dengan sporter (futsal), Olimpiade Penelitian Siswa Indonesia (OPSI), Festifal Inovasi Kewirausahaan Indonesia (FIKSI), Pramuka, Rohani Islam (Rohis), dan Organisasi Siswa Intra Sekolah (OSIS). Selain itu juga terdapat program lain seperti adanya literasi keagamaan, optimalisasi peran Bimbingan dan Konseling, dan penegakan tata 
tertib.

Dampak (effect) merupakan suatu hal yang muncul dari rencana atau program yang sudah dijalankan, seperti yang dijelaskan oleh Jones (1995) dalam Hasbullah (2008: 38). Dampak dari dilaksanakannya program-program tersebut adalah tindakan kekerasan yang dilakukan oleh siswa di sekolah menurun. Hal tersebut dapat dilihat dari aktivitas gang Barikade Bocah Cuek (BBC) selama lima tahun terakhir berkurang intensitas kekerasannya. Beberapa kekerasan seperti adanya sikap tawuran pelajar maupun sikap senioritas di sekolah sudah tidak terjadi.

Penjelasan diatas yang menjadi evaluasi adalah adanya penghapusan ekstrakurikuler yang berkaitan dengan supporter atau dalam hal ini penghapusan eksrakurikuler futsal. Penghapusan ekstrakurikuler ini disisi lain dapat mengurangi tindakan kekerasan di sekolah seperti adanya tawuran dan memicu perkelahian, juga dapat mematikan potensi siwa dalam hal olahraga futsal. Dapat dipastikan sekolah kehilangan salah satu bakat dari siswanya dalam bidang futsal. Siswa juga tidak mendapat ruang untuk menyalurkan potensinya dalam bidang futsal. Dan besar kemungkinan, siswa akan mencari pelarian untuk masuk kedalam gang Barikade Bocah Cuek (BBC). Sehingga perlu adanya penelitian lebih lanjut pada hal ini.

Optimalisasi peran Bimbingan Konseling disekolah untuk menangani kekerasan siswa di SMA Negeri 1 Depok Sleman Yogyakarta menjadi program yang efektif untuk dijalankan. Hal yang dapat dilakukan BK adalah dengan adanya konseling individu dan konseling kelompok. Peran konseling ini adalah dengan pendekatan secara personal kepada siswa. Sehingga Ketika siswa merasa nyaman dengan BK, siswa akan lebih terbuka untuk menerima saran-saran yang diberikan oleh guru BK. Maka dari itu peran BK harus lebih dioptimalkan kembali guna untuk menangani tindakan kekerasan siswa di SMA Negeri 1 Depok Sleman Yogyakarta.

\section{Pelaksanaan program sekolah dalam menangani kekerasan siswa di sekolah}

Kebijakan pendidikan yang didalamnya terdapat program-program pendidikan untuk dicapainya tujuan, maka haruslah diimplementasikan dengan baik. Menurut Hasbullah (2016: 99) dijelaskan bahwa Teori implementasi yang dikemukakan oleh Edward III yaitu terdapat empat variabel agar kebijakan menjadi efektif, yaitu communication (komunikasi), resource (sumberdaya), dispotition (sikap), dan bureaucratic structure (struktur birokrasi).

Komunikasi berhubungan dengan bagaimana kebijakan dikomunikasikan atau disebarluaskan kepada publik (Hasbullah, 2016: 99). Sedangkan proses komunikasi program sekolah dalam menangani kekerasan siswa di sekolah yaitu dilakukan komunikasi antara penyelenggara program dan pelaksana program. Proses komunikasi dilakukan dengan cara melibatkan birokrasi sekolah dan pengurus OSIS, bimbingan kelompok didalam kelas oleh guru BK, adanya sarasehan kesiswaan yang dihadiri oleh masing-masing ketua kelas dan ekstrakurikuler serta humas sekolah. Selain itu juga dilakukan publikasi menggunakan buku panduan peserta didik SMA Negeri 1 Depok Sleman Yogyakarta yang berisi rangkuman dari program sekolah yang bersifat akademik maupun non akademik kepada seluruh warga sekolah.

Sumber daya maunusia mencakup ketersediaannya untuk mengeksekusi atau menjalankan kebijakan yang berkenaan dengan kecakapan pelaksana kebijakan untuk mengimplementasikan kebijakan secara efektif (Hasbullah, 2016: 99). Sumber daya atau pihak yang terlibat dalam pelaksanaan program sekolah untuk menangani kekerasan siswa di sekolah adalah siswa, guru, guru BK, kepala sekolah, wakil kepala sekolah, maupun tim yang dibentuk untuk menangani kekerasan siswa di sekolah, salah satunya adalah tim ketertiban sekolah. Selain itu, ada 
juga tim yang bertugas untuk membantu tugas kepala sekolah dalam merencanakan, mempersiapkan, menyusun/ merevisi Rencana Kegiatan Jangka Menengah (RKJM) Tahun Ajaran 2016 sd 2020, Rencana Kerja Tahunan (RKT) Tahun Ajaran 2019-2020, serta dokumen lain yang relevan dalam pengembangan sekolah, tim tersebut adalah Tim Pengembang Sekolah (TPS).

Keseuaian organisasi birokrasi yang menjadi penyelenggara implementasi kebijakan dan tantangannya adalah supaya tidak terjadi bureaucratic pragmantation karena dapat menjadikan proses implementasi menjadi tidak efektif (Hasbullah, 2016: 99). Struktur birokrasi yang berperan dalam pelaksanaan program untuk menangani kekerasan siswa di sekolah yaitu kepala sekolah, wakil kepala sekolah, guru, dan perwakilan siswa seperti OSIS dan asing-masing ketua kelas atau ekstrakurikuler. Serta adanya peran guru BK dan wakil kepala sekolah bagian Dampak (effect) merupakan suatu hal yang muncul dari rencana atau program yang sudah dijalankan, seperti yang dijelaskan oleh Jones (1995) dalam Hasbullah (2008: 38). Dampak dari dilaksanakannya program-program tersebut adalah tindakan kekerasan yang dilakukan oleh siswa di sekolah menurun. Hal tersebut dapat dilihat dari aktivitas gang Barikade Bocah Cuek (BBC) selama lima tahun terakhir berkurang intensitas kekerasannya. Beberapa kekerasan seperti adanya sikap tawuran pelajar maupun sikap senioritas di sekolah sudah tidak terjadi.

Penjelasan diatas yang menjadi evaluasi adalah adanya penghapusan ekstrakurikuler yang berkaitan dengan supporter atau dalam hal ini penghapusan eksrakurikuler futsal. Penghapusan ekstrakurikuler ini disisi lain dapat mengurangi tindakan kekerasan di sekolah seperti adanya tawuran dan memicu perkelahian, juga dapat mematikan potensi siwa dalam hal olahraga futsal. Dapat dipastikan sekolah kehilangan salah satu bakat dari siswanya dalam bidang futsal. Siswa juga tidak mendapat ruang untuk menyalurkan potensinya dalam bidang futsal. Dan besar kemungkinan, siswa akan mencari pelarian untuk masuk kedalam gang Barikade Bocah Cuek (BBC). Sehingga perlu adanya penelitian lebih lanjut pada hal ini.
Optimalisasi peran Bimbingan Konseling disekolah untuk menangani kekerasan siswa di SMA Negeri 1 Depok Sleman Yogyakarta menjadi program yang efektif untuk dijalankan. Hal yang dapat dilakukan BK adalah dengan adanya konseling individu dan konseling kelompok. Peran konseling ini adalah dengan pendekatan secara personal kepada siswa. Sehingga Ketika siswa merasa nyaman dengan BK, siswa akan lebih terbuka untuk menerima saran-saran yang diberikan oleh guru BK. Maka dari itu peran BK harus lebih dioptimalkan kembali guna untuk menangani tindakan kekerasan siswa di SMA Negeri 1 Depok Sleman Yogyakarta.

Sumber daya maunusia mencakup ketersediaannya untuk mengeksekusi atau menjalankan kebijakan yang berkenaan dengan kecakapan pelaksana kebijakan untuk mengimplementasikan kebijakan secara efektif (Hasbullah, 2016: 99). Sumber daya atau pihak yang terlibat dalam pelaksanaan program sekolah untuk menangani kekerasan siswa di sekolah adalah siswa, guru, guru BK, kepala sekolah, wakil kepala sekolah, maupun tim yang dibentuk untuk menangani kekerasan siswa di sekolah, salah satunya adalah tim ketertiban sekolah. Selain itu, ada juga tim yang bertugas untuk membantu tugas kepala sekolah dalam merencanakan, mempersiapkan, menyusun/ merevisi Rencana Kegiatan Jangka Menengah (RKJM) Tahun Ajaran 2016 sd 2020, Rencana Kerja Tahunan (RKT) Tahun Ajaran 2019-2020, serta dokumen lain yang relevan dalam pengembangan sekolah, tim tersebut adalah Tim Pengembang Sekolah (TPS).

Keseuaian organisasi birokrasi yang menjadi penyelenggara implementasi kebijakan dan tantangannya adalah supaya tidak terjadi bureaucratic pragmantation karena dapat menjadikan proses implementasi menjadi tidak efektif (Hasbullah, 2016: 99). Struktur birokrasi yang berperan dalam pelaksanaan program untuk menangani kekerasan siswa di sekolah yaitu kepala sekolah, wakil kepala sekolah, guru, dan perwakilan siswa seperti OSIS dan asing-masing ketua kelas atau ekstrakurikuler. Serta adanya peran guru BK dan wakil kepala sekolah bagian kesiswaan yang langsung berinteraksi dengan masalah-masalah yang ada pada siswa.

Sikap berhubungan dengan kesediaan implementor untuk mengeksekusi kebijakan yang berkaitan dengan kesediaan dan komitmen untuk melaksanakan suatu kebijakan (Hasbullah, 2016: 99). Sedangkan di SMA Negeri 1 Depok Sleman Yogyakarta sikap pelaksana dalam pelaksanaan program sekolah untuk menangani kekerasan siswa 
di sekolah yaitu sebagaian besar menerima dan merespon denga baik jika ada program yang disepakati diawal, sehingga komtmen dari pelaksana dimunculkan. Akan tetapi untuk siswa- siswa tertentu yang memiliki kepentingan dengan gang cenderung kurang merespon dengan baik.

Aspek lain yang didapatkan daei hasil penelitian adalah adanya aspek sarana prasarana dan alokasi waktu dari sekolah untuk mengimplementasikan kebijakan sekolah dalam menagani kekerasan di sekolah. Sarana dan prasarana sekoalah dalam menangani kekerasan siswa di sekolah adalah ruangan seperti aula dan ruang BK yang digunakan untuk bimbingan klasila dan personal, maupun CCTV yang digunakan untuk pengecekan penegakan tata tertib siswa di sekolah agar tidak terjadi kekerasan siswa di skeolah. Selain itu uga ada sarana pengembangan diri agar siswa dapat mengekspresikan potensi yang dimiliki yaitu dengan adanya kegiatan pentas seni siswa di sekolah.

Alokasi waktu dalam pelaksanaan program sekolah untuk menangani kekerasan siswa di sekolah yaitu sekolah menerapkan penjadwalan waktu pada masing-masing program. Baik program yang bersifat akademik, ekstrakurikuler, maupun bimbingan dari BK. Sedangkan untuk bimbingan secara personal menyesuaikan kondisisesuai dengan kebutuhan siswa. Selain dari pihak skeolah termasuk guru memberikan pendekatan personal dan kultural kepada siswa dengan tujuan membuat siswa merasa nyaman dan dapat pula terbuka dengan guru, sehingga guru mudah mengarahkan siswa kepada hal-hal yang positif dan menjauhkan dari tindakan kekerasan siswa di sekolah.

Faktor Pendukung dan penghambat pelaksanaan program sekolah dalam menangani kekerasan siswa di sekolah

Faktor pendukung implementasi kebijakan pendidikan dijadikan sebagai kekuatan untuk dipertahankan, dan faktor penghambat implementasi kebijakan pendidikan dapat dijadikan kelemahan sebagai bahan evaluasi. Seperti yang dijelaskan oleh Arif Rohman dalam Solichin (2015:156) bahwa faktor pendukung dan penghambat implementasi kebijakan pendidikan yaitu: Kebijakan yang telah dibuat dan diambil dari pengambil kebijakan, dilihat dari aspek kalimat, sasaran, tingkat kepahaman, interpretasi, dan tingkat pelaksanaan; Personil pelaksana, dalam aspek tingkat pendidikan, pengalaman, motivasi, komitmen, kesetiaan, kinerja, kepercayaan diri, kebiasaan-kebiasaan, kemampuan kerjasama, latarbelakang budaya Bahasa dan ideologi; Sistem organisasi pelaksana, dalam aspek jaringan sistem, hirarki kewenangan masingmasing peran, model distribusi pekerjaan, gaya kepemimpinan dari pemimpin oragnisasi, atauran main organisasi, target masing-masing tahap yang ditetapkan, model monitoring yang biasa dipakai, dan evaluasi. Pembahasan terkait faktor pendukung dan penghambat dalam menangani kekerasan siswa di SMA Negeri 1 Depok Sleman Yogyakarta adalah sebagai berikut:

Faktor pendukung suatu kebijakan dapat dilihat dari salah satu aspeknya adalah tingkat kepahaman, hal tersebut dijelaskan oleh Arif Rohman dalam Solichin (2015:156). Tingkat kepahaman dibuktikan dengan adanya kerjasama dari seluruh warga sekolah. sehingga seluruh warga sekolah dapat bersinergi untuk melaksanakan program sekolah dalam menangani kekerasan siswa di sekolah.

Peran personil pelaksana juga sangat menentukan faktor pendukung untuk menangani kekerasan siswa di sekolah. Aspek dalam personil pelaksana ini dapat diidentifikasi dari aspek komitmen, kesetiaan, maupun kemampuan kerjasama. Bentuk kemampuan kerjasama untuk menangani kekerasan siswa di SMA Negeri 1 Depok Sleman Yogyakarta yaitu sinerginya antara kepala skeolah, karyawan, guru, guru BK, siswa, maupun stake holder sekolah.

Sistem organisasi pelaksana dalam aspek aturan-aturan dalam organisasi dijalankan dengan baik, serta adanya target-target pencapaian, dan monitoring evaluasi yang dilakukan dapat menjadi faktor pendukung dalam menangani kekerasan siswa di sekolah. SMA Negeri 1 Depok Sleman Yogyakarta dibentuk Tim Pengebang Sekolah yang bertugas untuk menyusun rencana kerja tahunan. 
Sehingga dalam perencanaan, implementasi, dan evaluasi program sekolah dalam menangani kekerasan maupun program secara keseluruhan dapat terkontrol dengan baik.

Faktor penghambat dalam pelaksanaan suatu kebijakan dipengaruhi salah satunya adalah dari personil pelaksana kebijakan pendidikan tersebut, seperti adanya tingkat pendidikan, pengalaman, motivasi, kesetiaan, kinerja, kepercayaan diri, kebiasaan-kebiasaan, kemampuan kerjasama, latarbelakang budaya, Bahasa, dan ideologi, hal tersebut dijelaskan oleh Arif Rohman dalam Solichin (2015:156). Faktor penghambat di SMA Negeri 1 Depok Sleman Yogyakarta dalam menangani kekerasan siswa di sekolah yaitu pada ideologi atau cara pandang orangtua yang salah terhadap anaknya. Hal tersebut terjadi karena orangtua tidak percaya pada sekolah bahwa anaknya terlibat kekerasan, karena adanya perbedaan karakter pada siswa ketika di rumah dan di sekolah. Sehingga terjadi ketimpangan yang menimbulkan ketikdapercayaan kepada sekolah.

Faktor penghambat dalam suatu kebijakan pendidikan dicarikan solusi untuk menanganinya. Sehingga efek-efek yang ditimbulkan tidak signifikan mengganggu jalannya suatu kebijakan. Dalam hal ini, cara mengatasi faktor penghambat dalam menangani kekerasan siswa di SMA Negeri 1 Depok Sleman Yogyakarta adalah dengan memberikan forum komunikasi antara orangtua, siswa, dan pihak skeolah. Menjelaskan dengan bukti-bukti yang valid, sehingga orangtua menaruh kepercayaan kepada sekolah, serta dapat berkerjasama untuk menangani siswa yang melakukan kekerasan di sekolah.

\section{SIMPULAN DAN SARAN}

\section{Simpulan}

1. Program sekolah dalam menangani kekerasan siswa di SMA Negeri 1 Depok Sleman Yogyakarta
Program yang dilaksanakan sekolah dalam menangani kekerasan siswa di SMA Negeri 1 Depok Sleman antara lain (1) pengawalan dan pengontrolan kegiatan kesiswaan yang terdiri dari penghapusan dan pelarangan ekstrakurikuler yang berkaitan dengan supporter (futsal), Olimpiade Penelitian Siswa Indonesia (OPSI), Festival Inovasi Kewirausahaan Indonesia (FIKSI), Pramuka, Rohani Islam (Rohis), Organisasi Siswa Intra Sekolah (OSIS); (2) Literasi keagmaan, hal ini; (3) optimalisasi peran Bimbingan dan Konseling,; (4) Penegakan tata tertib. Adanya program-program tersebut dianggap dapat menangani kekerasan siswa di SMA Negeri 1 Depok Sleman Yogyakarta.

2. Pelaksanaan program sekolah dalam menangani kekerasan siswa di SMA Negeri 1 Depok Sleman Yogyakarta

Pelaksanaan atau implementasi suatu kebijakan pendidikan dalam hal ini diturunkan menjadi program agar dapat berjalan dengan baik dan efektif maka dipengaruhi oleh empat aspek yaitu adanya komunikasi, sumberdaya, sikap, dan struktur birokrasi. Komunikasi sudah dilakukan dengan cara melibatkan birokrasi sekolah dan OSIS, bimbingan klasikal di dalam kelas oleh guru BK, sarasehan kesiswaan yang dihadiri oleh masing-masing ketua kelas dan ekstrakurikuler, serta menggunakan buku panduan peserta didi. Sumberdaya yang terlibat adalah seluruh warga sekolah baik birokrasi sekolah maupun siswa. Sikap pelaksana dapat menjalankan dengan baik jika adanya kesepakatan diawal, akan tetapi untuk siswa yang memiliki kepentigan maka cenderung merespon kurang baik. Sedangkan sturktur birokrasi dapat menjalankan perannya masing- masing dari pihak sekolah maupun lingkup siswa.

3. Faktor pendukung dan penghambat pelaksanaan program sekolah dalam menangani kekerasan siswa di SMA Negeri 1 Depok Sleman Yogyakarta

Faktor pendukung dalam melaksanakan program sekolah untuk menangani kekerasan siswa di sekolah yaitu adanya kerjasama dari seluruh warga sekolah, peran personil pelaksana, dan adanya sistem oragnisasi yang dijalankan dengan baik. Sedangkan faktor penghambatnya adalah cara pandang orangtua yang salah terhadap anaknya. Cara mengatasi faktor penghambat tersebut adalah dengan memberikan forum komunikasi diantara pihak yang terlibat dengan menjelasn bukti-bukti valid yang didapatkan dari sekolah. 


\section{Saran}

1. Bagi sekolah

Diperlukan peninjauan lebih lanjut tentang penghapusan ekstrakurikuler futsal atau yang berkaitan dengan supporter, dikarenakan setiap siswa memiliki potensi yang berbeda. Jika potensi dalam bidang tersebut tidak disalurkan dengan tepat, bisa jadi siswa-siswa akan beralih pada kegiatan yang negatif.

a Perlu adanya penambahan sumberdaya untuk mengelola kegiatan-kegiatan kesiswaan, sehingga tidak adanya rangkap tugas kerja dari salah satu orang saja.

b. Memaksimalkan fungsi Tim Pengembang Sekolah (TPS) untuk melakukan perencanaan, monitoring, dan evaluasi terhadap program sekolah untuk menangani kekerasan siswa di sekolah.

2. Bagi dinas pendidikan DIY

a Melakukan penelitian lebih lanjut pada sekolah-sekolah di DIY terkait kekerasan di sekolah, baik tingkat Sekolah Dasar/sederajat, Sekolah Menengah Pertama/sederajat, Sekolah Menengah Atas/sederajat, untuk mendeteksi adanya tindakan kekerasan di sekolah dan dapat segara dilakukan penanganan dan pencegahan.

b. Menyediakan forum upgrade untuk sekolah- sekolah dalam rangka perencanaan, implementasi, monitoring dan evaluasi program sekolah dalam rangka menangani kekerasan siswa di sekolah.

\section{DAFTAR PUSTAKA}

Assegaf, A.R. (2004). Pendidikan Tanpa Kekerasan. Yogyakarta: Tiara Wacana Yogya.

Dewi, K.C. (2015). Pengaruh Konformitas Teman Sebaya Terhadap Perilaku Bullying pada Siswa SMA Negeri 1 Depok, Yogyakarta. Yogyakarta: Program Studi Bimbingan dan Konseling Jurusan Psikologi Pendidikan dan Bimbingan Fakultas Ilmu Pendidikan Universitas Negeri Yogyakarta. Skripsi.

Efianingrum, A. (2009). Mengurai Akar Kekerasan (Bullying) di

Sekolah. Jurnal Dinamika.

Diambil tanggal 14 Maret 2018

dari :

http://staff.uny.ac.id/sites/defaut /files/Artikel\%20Dinamika\%20 2009.pdf.

Hasbullah. (2008) Dasar-Dasar Ilmu Pendidikan. Jakarta: PT Raja Grafindo Persada.

Hasbullah. (2016). Kebijakan Pendidikan Dalam Perspektif Teori, Aplikasi, dan Kondisi Objektif Pendidikan di Indonesia. Jakarta: Rajawali Pers.

Mulyasa, N, Dkk. (2018). Penanganan Anak Korban Kekerasan. Jurnal Hasil-Hasil Penelitian-ISSN Volume 13, Nomor 1. Diambil tanggal 4 Februari 2019 dari http://ejournal.iainkendari.ac.id

Narbuko, C. \& Achmadi, A. (2015). Metodologi Penelitian. Jakarta: PT Bumi Aksara

Solichin, M. (2015). Implementasi Kebijakan Pendidikan dan Peran Birokrasi. Jurnal Studi Islam Volume 6 Nomor 2. Diakses pada 16 Oktober 2019dari: file:///C:/Users/USER/Downloads/4 86- 919-1-SM.pdf. Syaodih, N. (2009). Metode Penelitian Pendidikan.Bandung: PT Remaja Rosdakarya Offset. 